\title{
Gênero e política: um olhar (estrangeiro) sobre a Princesa Isabel
}

\author{
Princess Isabel of Brazil: Gender \\ and Power in the Nineteenth \\ Century.
}

BARMAN, Roderick J.

Wilmington: Scholarly Resources, 2002. $291 \mathrm{p}$.

Recentemente, no ano de 2002, uma biografia da Princesa Isabel foi publicada nos Estados Unidos. Apesar de não ter sido traduzida para o português, um dos grandes méritos do livro em questão diz respeito ao caráter acadêmico da abordagem. Embora a figura da Princesa ainda esteja presente na memória dos brasileiros, até o presente momento as abordagens biográficas dedicadas a ela estavam marcadas por um teor laudatório, típico de uma história tradicional, preocupado em exaltar e engrandecer reis, rainhas, generais e comandantes.

Questionando a monopolização do passado por narrativas históricas masculinas, Barman propõe um olhar diferenciado em que o estudo de políticas e poder deixe de ser um espaço destinado unicamente ao estudo da ação e pensamento de homens. Embora reconheça que o esforço em dar presença e voz às mulheres tem sido lento, trabalhoso e insistentemente contestado, acredita no avanço de novas perspectivas que tornem as mulheres visíveis na história.

Diferenciando-se daquele tipo de abordagem tradicional mencionada acima, o historiador Roderick J. Barman propõe-se a tomar a vida de Isabel como um veículo de compreensão da interação entre gênero e poder no século XIX, no Brasil. Para tanto, procura empreender, segundo suas palavras, uma análise feminista da vida da Princesa. Nesse sentido é que desenvolve sua análise enfatizando a dificuldade de as mulheres do século XIX agirem de forma autônoma por serem moldadas e inseridas em estruturas culturais, sociais e econômicas criadas por homens aos quais eram subordinadas. É dentro desse quadro que Barman situa Isabel. Para ele, a Princesa estava presa a uma estrutura patriarcal rígida que a impedia de agir de modo autônomo.

A grande ênfase do livro está ligada à constatação, feita pelo historiador, de que mesmo tendo certo acesso aos recursos do poder, nas ocasiões em que exerceu a regência, durante as viagens do imperador D. Pedro II ao exterior, Isabel não conseguia se auto-afirmar e agir com independência. Segundo o autor, suas relações com seu pai, sua aia, e marido, e as condições nas quais ela serviu como regente foram quase todas desfavoráveis ao desenvolvimento de seu forte senso de desejo para agir. Tais relações aparecem como verdadeiras barreiras que impediam a herdeira do trono de almejar objetivos que ela escolhesse por si mesma.

Ou seja, Isabel, nascida em 1846, fazia parte de um grupo de mulheres, típicas das classes altas do Brasil oitocentista, que exerciam passivamente os papéis que a sociedade patriarcal ensinava a elas. Papéis como os de filha, noiva, esposa, mãe e regente. Como parte desse segmento, ela nunca se rebelou contra sua sorte em vida e raramente expressava algum tipo de descontentamento com isso. Ao contrário, teria aprendido desde a infância quais eram os deveres que sua sociedade e seu tempo the impunham.

Orientando-se por um modelo de ação feminista, previamente concebido, o autor, ao não encontrar tal perfil em sua biografada, acaba se frustrando e, em extrema oposição, faz uma leitura apressada e determinista de Isabel. Apresenta-a como uma figura passiva, sem vontade própria ou modo de interferência. A única exceção que o biógrafo encontra é justamente a assinatura da Lei Áurea. Para ele, no entanto, essa exceção serve para a confirmação da regra, uma vez que a libertação dos escravos teria contribuído para a exclusão da personagem de sua vida pública e a conseqüente queda do regime monárquico.

Enquanto os biógrafos tradicionais retratam uma princesa voluntariosa e determinada, portadora de uma visão política superior e destemida, Barman acaba por subestimar e, de certa forma, anular a experiência histórica de Isabel antes de sua terceira regência. Só 
consegue perceber sua ação autônoma em um único momento, em um ato de ruptura e de grande impacto. Antes de sua última regência, o autor insiste em retratá-la como desinteressada pelos negócios públicos e envolvida nos afazeres domésticos. Sua religiosidade também é apresentada como parte importante da constituição de sua personalidade. O autor, contudo, nesse aspecto, não acrescenta mais do que os outros biógrafos já haviam afirmado. É importante notar que a preocupação central de Barman gira em torno da questão de gênero, na qual insere a religiosidade de Isabel, sem maiores problematizações.

Grosso modo, os biógrafos da Princesa Isabel, inclusive Barman, são unânimes em reconhecer a defesa dos bispos empreendida por Isabel, na chamada "Questão Religiosa", uma atitude que atesta sua filiação ao ultramontanismo. ${ }^{1}$ Esse fator, acrescido à sua intensa devoção religiosa, teria contribuído fortemente para o crescimento de sua impopularidade junto aos meios políticos oitocentistas, temerosos de uma possível sobreposição católica na política imperial. No entanto, lamentavelmente, nem mesmo Barman abordou, com a profundidade devida, as possíveis implicações que esse ultramontanismo possa ter assumido na experiência da Princesa. Vale ressaltar que o Terceiro Reinado, sob o governo de Isabel, certamente existiu como projeto, apesar de ter sido severamente criticado por republicanos e até por monarquistas, simpáticos a um governo de D. Pedro Augusto. ${ }^{2}$ Provavelmente, não como um projeto elaborado em bases teóricas escritas e com propostas e planejamentos bem delineados e formalizados. Mas como uma perspectiva futura, que, de antemão, exigia de Isabel uma postura específica, tanto mais visível quanto mais ameaçada e questionada.

Esse aspecto, se explorado, poderia contribuir para uma visão menos determinista da biografada. Não há dúvida de que Isabel vivia em uma sociedade patriarcal e governada por homens, mas o que se percebe é que sua religiosidade, mesmo guardando um sentido retrógrado, incomodava os padrões políticos vigentes no cenário oitocentista. Essa poderia muito bem ser a chave de ação da Princesa como forma de contestar o rígido sistema em que vivia. Ao se colocar como católica fervorosa, Isabel opunha-se politicamente ao modo de condução das transformações presentes em seu tempo e, assim, agia de modo a afirmar seu pensamento e sua visão de mundo. Ou seja, mesmo que de forma reacionária e ultraconservadora, seu modelo de transformação da sociedade vinha das propostas religiosas, por meio das quais se inseria naquele mundo. A resistência e a agência poderiam servir-se desses meios reacionários, mas, infelizmente o biógrafo não explora essa perspectiva, o que o leva a ignorar a diferença entre as expectativas preconceituosas projetadas sobre a figura daquela que seria a futura imperatriz e o que de fato ela configurava em sua própria experiência.

O livro é composto por oito capítulos que perfazem um total de 291 páginas. Após o primeiro capítulo, em que o leitor encontra uma discussão em torno das relações entre gênero e poder no Brasil do século XIX, os capítulos seguintes obedecem a uma divisão marcada pelo que Barman chamou de ciclos da vida feminina da Princesa como: filha, noiva, esposa, mãe, regente. O penúltimo e sétimo capítulo dedica-se ao estudo da vida da Princesa após a queda da monarquia, no período em que viveu exilada na França até 1921, quando faleceu. Por fim, no oitavo e último capítulo, intitulado "Reflections", encontramos as observações finais, em que o autor reconstitui, em síntese, os principais argumentos e conclusões do que foi esboçado e desenvolvido ao longo da biografia.

Por ser uma publicação estrangeira, diferencia-se positivamente em dois aspectos gráficos em relação às nossas editoras brasileiras. O primeiro ponto diz respeito à composição de um índex, ao final do livro. Tal recurso, pouco explorado em nossas edições, constitui uma ferramenta importante para pesquisadores e leitores especializados. O segundo aspecto, que também favorece o público leigo em geral, está relacionado à ampla utilização de fotografias que podem ser observadas ao longo de todos os capítulos. Infelizmente, as publicações nacionais dedicam, em geral, pouca atenção a esses elementos. Em termos de aspectos gráficos, também merece destaque uma interessante, embora pequena, lista de bibliografia comentada, igualmente situada ao final do livro.

De uma forma geral, o livro é bem escrito e merece a atenção de todos aqueles interessados em investir nas abordagens feministas da História do Brasil. As críticas aqui apresentadas devem ser tomadas como estímulo a novas investidas nesse campo fértil e ainda pouco explorado de nosso passado histórico. Assim, poderemos, com o passar do tempo, promover sínteses que lancem novas luzes sobre a ação das mulheres em nossa História. As abordagens tradicionais, e mesmo os estudos mais recentes, não podem, em nenhuma 
hipótese, cristalizar imagens de nossas personagens que se tornem aceitas como definitivas. Novos trabalhos, imbuídos de novas problematizações e questionamentos, serão sempre bem-vindos. Com isso, a história brasileira e de seus diversos segmentos continuará a ser constantemente reescrita em um exercício que, em última instância, proporciona a formação de uma consciência cidadã.

' Um movimento católico conservador que se expandiu, ao longo do século XIX, como resposta ao crescimento de movimentos laicizantes diversos como o liberalismo, o socialismo, o positivismo, entre outros, marcados pela defesa de uma sociedade mais racional e com menor interferência da religião na políica.
2 D. Pedro Augusto era o filho mais velho da Princesa Leopoldina, falecida em 1871, irmã da Princesa Isabel. Neto mais velho do Imperador, era cogitado por alguns monarquistas como a melhor opção para a continuidade do regime. Cogitava-se, inclusive, que o próprio $\mathrm{D}$. Pedro Il pensava em preparar a sucessão para esse neto, projeto abandonado em função de sinais de insanidade mental dados pelo rapaz. Cf. SCHWARCZ, Lilia Moritz. As barbas do Imperador: D. Pedro II, um monarca nos trópicos. São Paulo: Companhia das Letras, 1998. p. 433.

Robert Daibert Junior Universidade Federal do Rio de Janeiro 